\title{
Effects of Water Application Rate and Leaching Method on Reclamation of a Coastal Salt- Affected Soil of Harawah Region, Libya
}

\section{R.M. R. Hedia}

Soil and Water Sciences Department, Faculty of Agriculture, Alexandria University, Alexandria, Egypt.

\begin{abstract}
D ECLAMATION of salt-affected soils depends on many factors related to soil properties, water availability and quality, method of leaching and irrigation systems. This study aimed at investigating the effects of both water supplication rate and the leaching method in reclaiming a calcareous salt-affected coastal soil $(\mathrm{EC}=36.76 \mathrm{dS} \mathrm{m}-1$ $\mathrm{ESP}=23.8 \% \mathrm{pH}=8.38)$ using the water of the Man-made River $(\mathrm{EC}=$ $1.48 \mathrm{dS} \mathrm{m}-1$ and SAR= 3.71). Disturbed soil samples were collected from the study area to a depth of $50 \mathrm{~cm}$ and packed into PVC cylinders $(60 \mathrm{~cm}$ long and $10 \mathrm{~cm}$ i.d.).The experiment comprised the treatments of seven water application rates expressed by the average pore volume of the soil columns $(0,2,4,6,8,10$ and $12 \mathrm{PV})$ and two leaching methods; continuous (CL) and discontinuous (DL) using a factorial design with three replications for each treatment. Soil EC, ESP and $\mathrm{pH}$ were determined and their relative changes to the initial values were calculated (ECrel, ESPrel and pHrel) and plotted against the number of PV of applied water to obtain the leaching curves. Reductions in parameters were significant with increasing the number of PV of water applied. The DL method proved to be more efficient than the CL method in reducing these soil parameters to acceptable levels $(\mathrm{EC}=2.61 \mathrm{dS} \mathrm{m}-1, \mathrm{ESP}=4.61 \%$ and $\mathrm{pH}=7.78)$ when $10 \mathrm{PV}$ of water was applied. This means that less water and longer time period will be required if the DL method is adopted. Further field research must be conducted to account for field soil variability, efficiency of irrigation systems and climate and crop conditions.
\end{abstract}

Keywords: Salt-affected soil, Water application rate, Leaching method, Leaching curves, Efficiency.

Salts are the bane of both irrigated agriculture and of civilizations that are based on it, particularly if irrigation water and drainage are improperly managed. Excess salts in surface soils are a common condition in arid and semiarid regions (Szabolcs, 1989). The impacts that excess salts have on soil physical and chemical characteristics depends on the type of salts present in soil or irrigation water. Recent data indicate that poor irrigation practices result in the loss of an estimate of 10 million hectares of arable lands per year as a result of soil salinization (Essington, 2004). 
Soils adjacent to oceans or other bodies of brackish water can receive cyclic salts. These soils may become salinized through the tidal actions or seepage, where the degree of salinization depends on climate, tidal character, hydrology and soil properties (Massoud, 1981). Under such conditions, these soils tend to be extremely saline. Therefore, irrigation water management in these regions must strike a balance between conservation and the needs of agricultural production (Ayers and Westcot, 1985).

Libya has about $1900 \mathrm{~km}$ long of coastal line along the Mediterranean Sea. Thousands of hectares along this coastal line are salt affected soil due to tidal action, windblown sea water spray and/or saline ground waters (Abdulaziz, 2005). About $80 \%$ of the Man-made River water budget is allocated for agricultural reclamation projects along the coastal line (GMRP, 1995). The saline soils are low-lying areas adjacent to sea shores where coastal soils are frequently support halophytic vegetation. Harawah region, located in Sirt Governorate is a region having the largest areas of saline soils on the Libyan coastal line. This condition restricts the extension in reclaiming more areas in this region (Bresler et al., 1982 and Rengasam \& Olsson, 1991).

Traditionally, there are two methods of leaching, i.e., continuous leaching (CL) and discontinuous (intermittent) leaching (DL). Continuous leaching is accomplished by continuously ponding of water on the soil surface and in discontinuous leaching ponded water application is interrupted to allow the redistribution of water and salts held in macro pores (Gupta and Gupta, 1987and Tagar et al., 2010). Continuous ponding is the preferred method when time is a limiting factor. This method can pass the same amount of water through the soil profile much faster. As a general rule, this type of leaching will require one centimeter of water for each centimeter unit of the soil profile to be reclaimed. However, the amount of water needed for leaching will vary, depending on the texture of the soil. If water resource availability is a limiting factor, the discontinuous method is adopted for reclamation (Gupta and Gupta, 1987). Thus, the objective of this study was to investigate the effects of water application rate and the method of leaching on reducing of salinity of a Sabkha soil from Harawah region.

\section{Materila and Methods}

Soil sampling

Soil sampling was carried out from one of the largest Sabkha areas in Harawah region located $75 \mathrm{~km}$ east of Sirt city along the coastal road of Libya $\left(31^{\circ} 03^{\prime} 47.37^{\prime}\right.$ ' N, $17^{\circ} 18^{\prime} 13.02$ " E). Both disturbed and undisturbed samples were collected to a depth of $50 \mathrm{~cm}$. Some physical and chemical characteristics of the soil were determined according to Page et al. (1982) and Klute (1986) are shown in Table 1. 
EFFECTS OF WATER APPLICATION RATE AND LEACHING METHOD... 123

TABLE 1. Some selected chemical and physical characteristics of the studied soil.

\begin{tabular}{|c|c|c|c|c|c|c|c|c|c|}
\hline \multirow{2}{*}{$\begin{array}{c}\text { Soil depth } \\
\text { cm }\end{array}$} & \multirow[t]{2}{*}{ pH } & \multirow{2}{*}{$\begin{array}{c}E C \\
\mathrm{dS} \mathrm{m^{-1 }}\end{array}$} & \multirow{2}{*}{$\begin{array}{c}\text { Total } \\
\mathrm{CaCO}_{3}, \%\end{array}$} & \multirow[t]{2}{*}{ SAR } & \multirow{2}{*}{$\begin{array}{c}\text { Bulk } \\
\text { density } \\
\text { kg m}^{-3}\end{array}$} & \multirow[t]{2}{*}{ Texture } & \multicolumn{3}{|c|}{$\begin{array}{c}\text { Moisture } \\
\text { characteristics, \%v }\end{array}$} \\
\hline & & & & & & & SP & FC & WP \\
\hline & 1 & & & 25.3 & 1631 & & & & 5.8 \\
\hline $5-25$ & 37 & & & 21.4 & 16 & $\mathrm{~L}$ & 3 & & 5.6 \\
\hline $25-50$ & 8.36 & 28.11 & 10.42 & 19.4 & 1712 & Sandy & 34.3 & 12.7 & 5.3 \\
\hline
\end{tabular}

SP: Saturation Percent. $\quad$ FC: Field Capacity.

WP:Welting Point.

\section{Soil columns}

PVC cylinders (60 $\mathrm{cm}$ long and $10 \mathrm{~cm}$ inside diameter) were sealed from one end (bottom) using PE square sheets $(12 \times 12 \mathrm{~cm})$ with a central drainage hole. The cylinders' bottoms were lined with PVC screen and 1-2 mm gravels to a depth of $2.0 \mathrm{~cm}$. The disturbed soil layers were packed into the cylinders to a 50 $\mathrm{cm}$ height according to their field arrangement and corresponding bulk densities (Sherif and Hedia, 2004). The average pore volume (PV) of the packed soil columns was calculated using the average total porosity and total volume of the soil column. An average calculated PV of $1450 \mathrm{ml}$ was used as a reference value of the applied water to soil columns (Gharaibeh et al., 2012). Each pore volume represented the amount of water required to saturate all soil pores and this was equivalent to $18.47 \mathrm{~cm}$ of leaching water.

\section{Soil amendments}

Gypsum was applied to the soil columns at the rate of $50 \mathrm{t} / \mathrm{ha}$, spread on the top and mixed with the upper $10 \mathrm{~cm}$ of soil column before carrying the leaching session (Gharaibeh et al., 2012).

\section{Irrigation water}

Irrigation water, supplied from the Gerdabeya Reservoir of the Man-made River Project to the experimental farm of Sirt University, was used in the current study. Analysis of this source was carried out (Page et al., 1982) which showed that its EC, pH and SAR were $1.48 \mathrm{dS} \mathrm{m}-1,7.66$ and 3.71, respectively.

\section{Leaching treatments}

The effects of both water application rates and the leaching method were investigated in this study. Seven levels of water application rates were designed to represent $0,2,4,6,8,10$ and 12 multiples of the PV of soil columns. For each water application rate, two leaching methods; continuous leaching (CL) and discontinuous leaching (DL) were applied. In the continuous leaching method, the desired amount of water was continuously applied keeping a water head of $3.0 \mathrm{~cm}$ on the soil surface. In the discontinuous method, the desired volume of water was applied as one-half PV per $48 \mathrm{hr}$ to allow for complete free drainage (Gharaibeh et al., 2012). The surfaces of the soil columns were covered to minimize evaporation. Treatments were carried out in triplicates. 
At the end of each leaching treatment, the PVC cylinders were longitudinally split using an electric rotating saw disc to have the soil column. The soil columns were divided into two sections; the top $5 \mathrm{~cm}$ and the rest of the soil column. Each section was air-dried, thoroughly mixed and representative samples were used to obtain soil paste extracts for the determination of ECe, $\mathrm{pH}$ and soluble $\mathrm{Ca}^{+2}$, $\mathrm{Mg}^{+2}$ and $\mathrm{Na}^{+}$ions and the soil SAR values were calculated. The obtained SAR values were used to calculate the soil ESP using the following expression (U.S. Salinity Lab Staff, 1954);

$$
E S P=\frac{100(-0.0126+0.01475 S A R)}{1+(-0.0126+0.01475 S A R)}
$$

Leaching curves were established by plotting relative changes in soil salinity, $\mathrm{ECrel}=\left(\mathrm{EC}_{-} \mathrm{EC}_{\mathrm{eq}}\right) /\left(\mathrm{EC} 0-\mathrm{EC}_{\mathrm{eq}}\right)$ on the ordinate and the amount of applied water expressed by the number of PV on the abscissa, where EC is the average soil salinity after an application of specified depth of leaching water, $\left(\mathrm{EC}_{\mathrm{o}}\right)$ is the initial salinity of soil, and ECeq is the salinity of soil at the end of reclamation process. $\mathrm{EC}_{\mathrm{eq}}$ is equal to the salinity of the upper $5 \mathrm{~cm}$ of reclaimed soil. When $\mathrm{EC}_{\mathrm{eq}}$ is subtracted both from initial soil salinity $\left(\mathrm{EC}_{\mathrm{o}}\right)$ and salinity of soil after application of specified leaching depth (EC), the relationship becomes independent of salinity of irrigation water and evaporation conditions (Gharaibeh et al., 2012). The ECrel will take values from 1.0, for the untreated soil (EC= $\mathrm{EC}_{0}$ ) to 0.0 , when the soil $\mathrm{EC}$ reaches that of applied water. Similarly, soil $\mathrm{pH}$ and desodification curves were constructed by plotting relative changes in soil $\mathrm{pH}\left(\mathrm{pH}_{\mathrm{rel}}\right)$ and $\mathrm{ESP}\left(\mathrm{ESP}_{\mathrm{rel}}\right)$ on the ordinate and PV on the abscissa.

\section{Statistical analysis}

The two-way completely randomized design of the applied treatments was used to carry out the statistical analysis of the obtained data to test significance of the effects of water application rates and the leaching method on the calculated parameters $\left(\mathrm{EC}_{\mathrm{rel}}, \mathrm{pH}_{\mathrm{rel}}\right.$ and $\left.\mathrm{ESP}_{\mathrm{rel}}\right)$.

\section{Results and Discussion}

Leaching experiments in the field is not feasible to carry out since they are known to be time-consuming and expensive. Therefore, column leaching experiments were used for this purpose. Leaching curves are useful tools to determine the efficiency of amendments and the required amount of water needed for successful reclamation.

Leaching curves that describes the relationship between the number of PV of applied water and the resulted reduction in soil salinity (desalinization) are shown in Fig. 1. Reduction in $\mathrm{EC}_{\text {rel }}$ values of the soil columns were increased with increasing the water application rates. $\mathrm{EC}_{\text {rel }}$ values were reduced from 1.0 in the control to 0.076 and 0.033 after adding $12 \mathrm{PV}$ of leaching water for the 
continuous leaching (CL) and discontinuous leaching (DL) methods, respectively. This means that the average EC of the soil was reduced from $36.76 \mathrm{dS} \mathrm{m}^{-1}$ in the control to 4.15 and $2.61 \mathrm{dS} \mathrm{m}^{-1}$, for these two methods respectively. It seems that the DL method was more efficient than the CL method in reducing the soil salinity to an acceptable level for cultivation $\left(<4 \mathrm{dS} \mathrm{m}^{-1}\right)$. The ECrel values under the CL method were initially lower than those of the DL method (PV=4). After that, the ECrel values of the DL method tend to be lower than those of the CL method. This may be attributed to the very high initial soil salinity of the soil columns which facilitated the removal of larger amounts of soluble salts with the continuous flowing leaching water along the soil macro pores (Gupta and Gupta, 1987). As the soil salinity is further decreased, more time was needed to dissolve and remove soluble salts from the smaller soil pores. Keren and Miyamoto (1990) and Gharaibeh et al. (2012) stated that continuous ponding (carried out under near saturated soil-water conditions) usually required more water than intermittent ponding (carried out under unsaturated conditions). Thus, the efficiency of leaching increased as the contents of the soil water decreased during leaching and the range of soil pore size distribution also affected salt leaching.

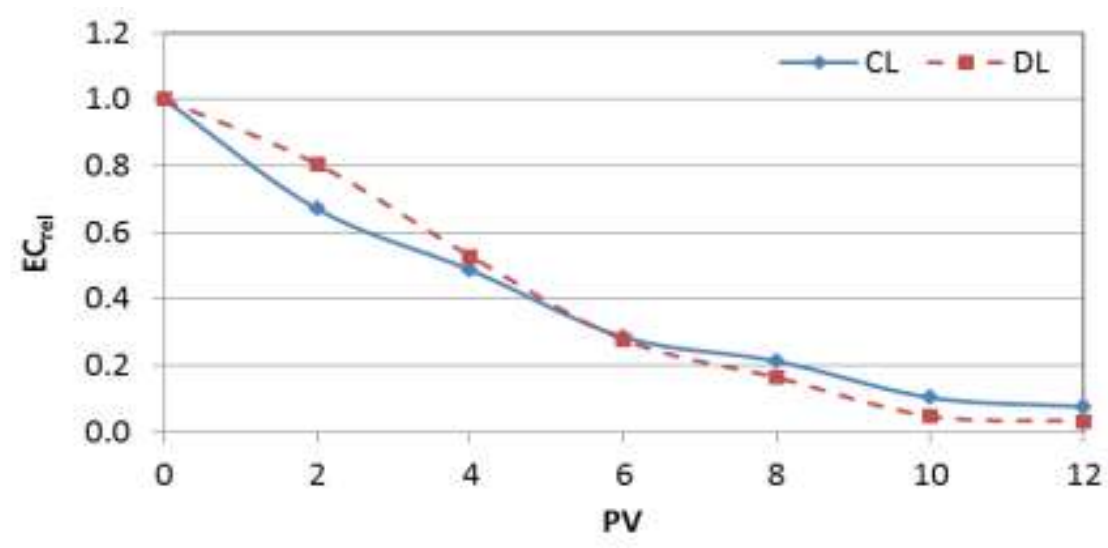

Fig. 1. Relative changes in soil salinity $\left(\mathbf{E C}_{\text {rel }}\right)$ as affected by water application rate expressed as PV and the continuous (CL) and discontinuous (DL) leaching methods.

Statistical analysis of the obtained data (Table 2) revealed that there were significant differences between the number of PV of applied water and the reduction of $\mathrm{EC}_{\mathrm{rel}}$ of the leached soil columns under the two leaching methods. In addition, the DL leaching method resulted in significantly lower $\mathrm{EC}_{\text {rel }}$ (higher leaching efficiency) than those for the CL method under all water application rates. 
TABLE 2. Significant differences between means of the tested water application rates and leaching methods treatments.

\begin{tabular}{|c|ccc|}
\hline \multirow{2}{*}{ Treatments } & \multicolumn{3}{|c|}{ Means Values } \\
\cline { 2 - 4 } & EC $_{\text {rel }}$ & $\mathbf{E S P}_{\text {rel }}$ & $\mathbf{p H}_{\text {rel }}$ \\
\hline Water Appl. Rate (PV) & & & \\
0 & $1.000 \mathrm{a}$ & $1.000 \mathrm{a}$ & $1.000 \mathrm{a}$ \\
2 & $0.739 \mathrm{~b}$ & $0.853 \mathrm{~b}$ & $0.913 \mathrm{~b}$ \\
4 & $0.507 \mathrm{c}$ & $0.677 \mathrm{c}$ & $0.770 \mathrm{c}$ \\
6 & $0.282 \mathrm{~d}$ & $0.485 \mathrm{~d}$ & $0.586 \mathrm{~d}$ \\
8 & $0.188 \mathrm{e}$ & $0.357 \mathrm{e}$ & $0.298 \mathrm{e}$ \\
10 & $0.065 \mathrm{f}$ & $0.141 \mathrm{f}$ & $0.260 \mathrm{f}$ \\
12 & $0.059 \mathrm{f}$ & $0.138 \mathrm{f}$ & $0.253 \mathrm{f}$ \\
LSD.05(n=6) & 0.0069 & 0.0095 & 0.0078 \\
Sign. Degree & $* * *$ & $* * *$ & $* * *$ \\
\hline Leaching Method & & & \\
CL & $0.408 \mathrm{a}$ & $0.559 \mathrm{a}$ & $0.593 \mathrm{a}$ \\
DL & $0.404 \mathrm{~b}$ & $0.485 \mathrm{~b}$ & $0.571 \mathrm{~b}$ \\
LSD.05(n=21) & 0.0029 & 0.0035 & 0.0042 \\
Sign. Degree & $* *$ & $* *$ & $*$ \\
\hline Appl. Rate x Leach. Method & $* * *$ & $* *$ & $\mathrm{~ns}$ \\
\hline
\end{tabular}

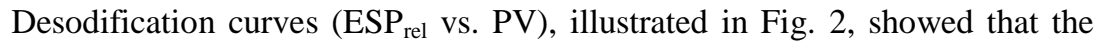
progressive decreases of $\mathrm{ESP}_{\text {rel }}$ by increasing the amount of applied leaching water were recorded under the two leaching methods. The $\mathrm{ESP}_{\text {rel }}$ of the control soil was reduced to 0.183 and 0.064 for CL and DL leaching methods, respectively. This means that the soil ESP was reduced from $23.8 \%$ to 7.05 and $4.62 \%$, respectively. However, increasing the amount of applied water from 10 to $12 \mathrm{PV}$ had not any significant effect on decreasing the $\mathrm{EC}_{\mathrm{rel}}$. Both application rate of water and method of leaching had significant effects on reducing the $\mathrm{ESP}_{\text {rel }}$ (Table 2). The DL method was found to be significantly more efficient than the CL method in reclaiming the sodicity of the soil. The longer time period needed in the DL method facilitated conditions for better dissolution of gypsum and increase the replacement of $\mathrm{Ca}$ ions with the soil exchangeable $\mathrm{Na}$.

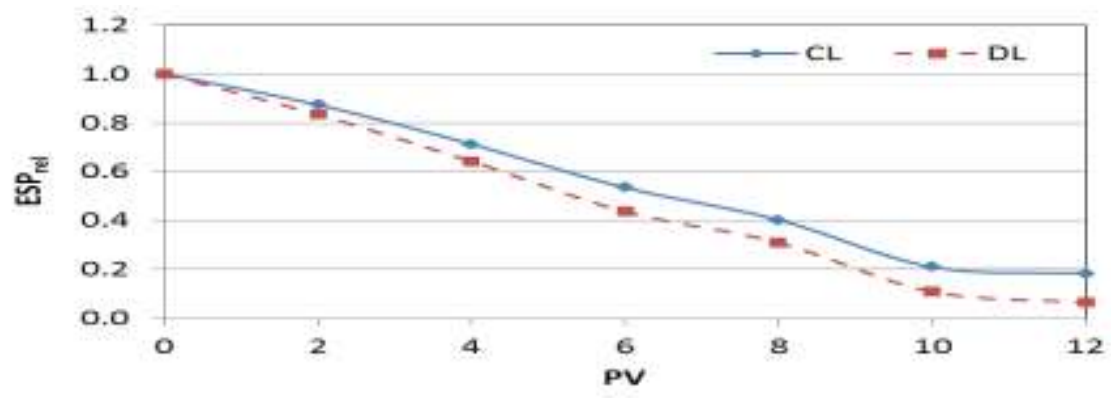

Fig. 2. Relative changes in soil sodicity $\left(\mathrm{ESP}_{\text {rel }}\right)$ as affected by water application rate (PV) and the CL and DL methods.

Egypt. J. Soil Sci. 54, No. 2 (2014) 
Reductions in the soil $\mathrm{pH}$ due to the tested leaching treatments followed the same trends of the desalinization and desodification curves previously described. However, increasing the amount of applied water from 10 to $12 \mathrm{PV}$ did have significant effect on decreasing the $\mathrm{pH}_{\text {rel }}$. The $\mathrm{pH}_{\text {rel }}$ of the control soil was reduced from 1.00 to 0.181 and 0.180 for the CL and DL leaching methods, respectively. This means that the soil $\mathrm{pH}$ was reduced from 8.38 to 7.79 and 7.78, respectively. Similarly, the efficiency of the DL leaching method was significantly more efficient than the CL method in reducing the soil $\mathrm{pH}$ (Table 2) (Fig. 3).

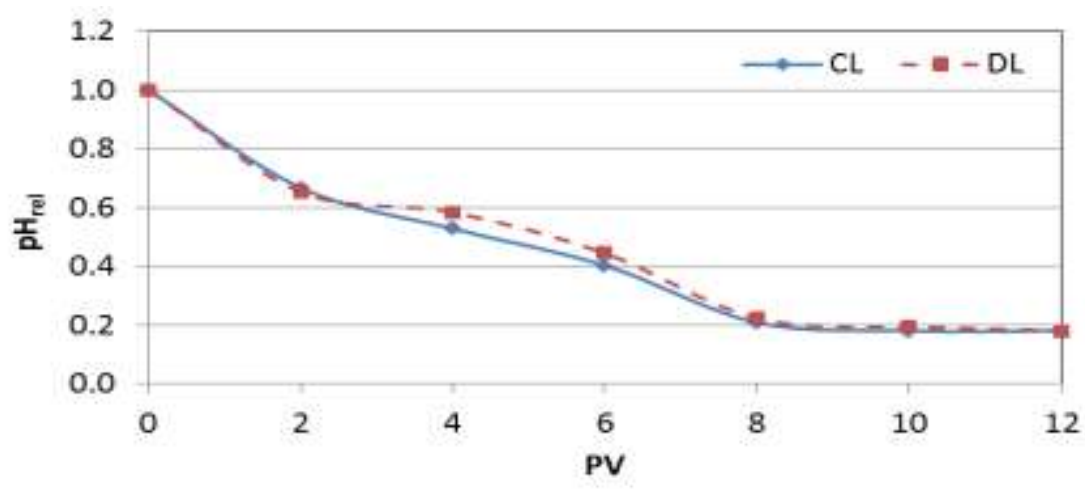

Fig. 3. Relative changes in soil acidity $\left(\mathrm{pH}_{\text {rel }}\right)$ as affected by water application rate (PV) and the CL and DL methods.

From all the aforementioned findings, the DL leaching proved to be significantly more efficient in eliminating salinity and sodicity of the tested soil to acceptable levels compared with the CL method. The amount of leaching water equivalent $12 \mathrm{PV}$ was calculated to be about $18471 \mathrm{~m}^{3} \mathrm{ha}^{-1}$. For field applications, evaporative conditions, efficiency of the applied irrigation system and spatial soil variability should be considered.

\section{Conclusion}

The efficiency of the optimum depth of leaching water and the method of leaching can be evaluated using the leaching curves as a tool for successful reclamation. The depth of water needed to reduce the salt content for a given application rate can be calculated from desalination graphs. Desalinization and desodification leaching curves showed that the Harawah calcareous saline-sodic soil could be reclaimed efficiently using the Man-made River water. The application of $50 \mathrm{~kg}$ ha-1 gypsum and an equivalent of $12 \mathrm{PV}$ leaching water using the discontinuous leaching method substantially reduced soil salinity and sodicity to acceptable levels. The amount of water required for leaching salts from soil columns can be minimized by discontinuous method but with longer time period needed for reclamation compared with the continuous method. 
However, further field experimentation is required before any certain recommendation is drawn to account for field evaporative conditions, efficiency of irrigation systems and field spatial variability of soil properties.

Aknowldgement: The author wishes to express his gratitude to the Soil and Water Sciences Department, Faculty of Agriculture, Sirt University for the facilities support to this work.

\section{References}

Abdulaziz, A. M. (2005) Water quality assessment of the Great Man-made River for sustainable water resources management. Ph.D. Thesis, Institute of Graduate Studies and Research, Alexandria, Univ., Egypt.

Ayers, R. S. and Westcot, D. W. (1985) Water quality for agriculture. FAO Irrigation and Drainage, Papers 29, Rome.

Bresler, E., McNeal and Carter, B. L. (1982) "Saline and Sodic Soils", Springer Verlage, Berline.

Essington, M. E. (2004) Soil and Water Chemistry: An integrative approach, CRC Press, Washington, D.C.

Gharaibeh, M. A., Eltaif, N. I. and Shra'a, S. H. (2012) Desalination and Desodification curves of highly saline-sodic soil amended with phosphoric acid and by-Product Gypsum. Inter. J. Environ. Sci. Develop. 3:39-42

GMRP (1995) The Great Man-made River Project. Final Report, Section 2: Crop rotations, crop water requirement and design of irrigation systems. GMR Authority.

Gupta, S.K. and Gupta, I. C. (1987) Land development and leaching. In: "Management of Saline Soils and Waters", pp. 136-152, New Dehli, Mohan Primlani.

Keren, R. and Miyamoto, S. (1990) Reclamation of Saline, Sodic, and Boron Affected Soils. In: "Agricultural Salinity Assessment and Management", K. K. Tanji (Ed.), pp. 410-431, ASCE. manuals and reports on engineering practices \# 71, New York, ASCE.

Klute, A. (1986) "Method of Soil Analysis", Part I., $2^{\text {nd }}$ ed., Agron. Monogr. 9., ASA, Madison, WI.

Massoud, F. J. (1981) Salt-affected soils at a global scale and concept of control. Tech. Papers FAO Land and Water Development Div., Rome.

Page, A. L., Miller, R. H. and Keeney, D. R. (1982) "Method of Soil Analysis", Part II, $2^{\text {nd }}$ ed., Agron. Monogr. 9, Madison, Wisconson, U. S. A.. 
EFFECTS OF WATER APPLICATION RATE AND LEACHING METHOD... 129

Rengasam, P. and Olsson, K. A. (1991) Sodicity and soil structure. Aust. J. Soil Res. 29: 935-952.

Sherif, F. K. and Hedia, R. M. R. (2004) Evaluation of resin capsules for monitoring the availability and movement of nutrients in Egyptian soils. Alex. J. Agric. Res. 49:119128.

Szabolcs, I. (1989) "Salt-Affected Soils", CRC Press, Boca Raton, FL.

Tagar, A. A., Siyal, A. A., Brohi, A. D. and Mehmood, F. (2010) Comparison of continuous and intermittent leaching methods for the reclamation of a saline soil. Pak. J. Agric., Agric. Eng., Vet. Sci. 26: 36-47.

U. S. Salinity Lab Staff (1954) "Diagnosis and Improvement of Saline And Sodic Soils", L.A. Richards (Ed.), USDA Agric Handbook No. 6., Washington, D.C.

(Received 22/5/2013;

accepted 25/9/2014) 


\section{تأثير مـعدل إضافـة الماء وطريقة الغسيل على استصلاح تربة

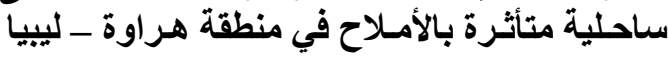 \\ رمـزي مـرسي رزق هديـة

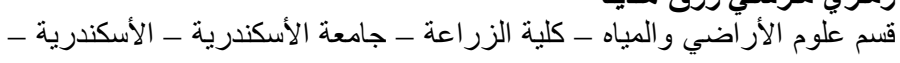

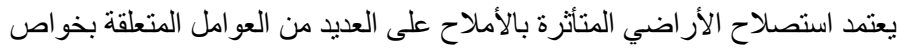

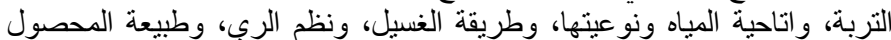

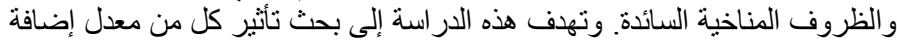

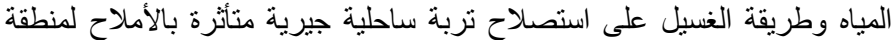

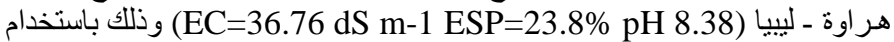
مياه النهر الصناعي (EC=1.48 dS m-1 and SAR=3.71). عينات تربة سطحية مفككة من منطقة الدراسة إلى عمق 50 سم ، وتم تعلى تعبئتها في

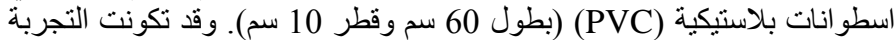

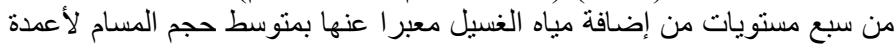
التربة (0, 2, 4, 6, 8, 10 and 12 PV) وطريقتين من طرق الغسيل: طريقة

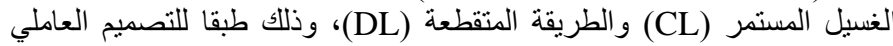

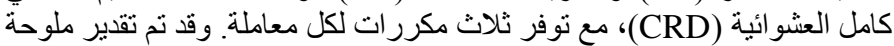

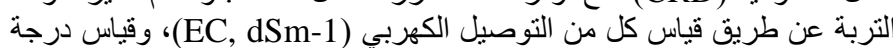

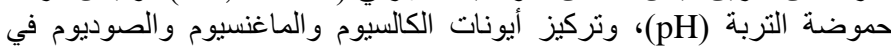

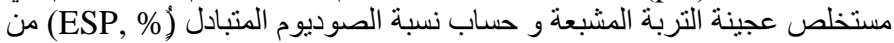
قيم (SAR) المحسوبة. ولتقييم عملية الغسيل تم رسم منحنيات الغسيل و التي تمثل العلاقة البيانية بين التغير النسبي للصفات المدروسة

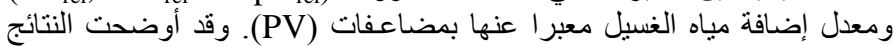

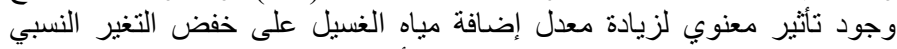

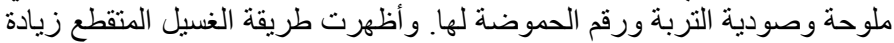
معنوية في كفاءة الغسيل وخفض خصائل

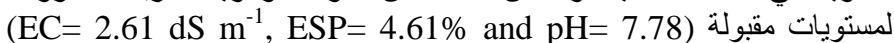

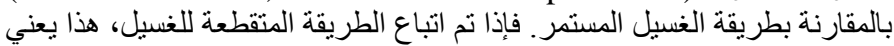

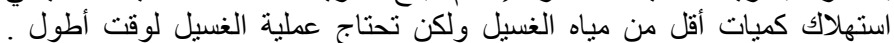

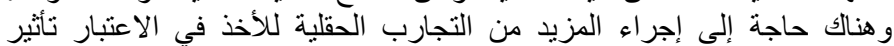

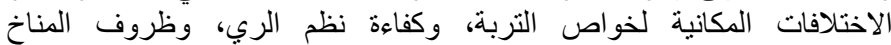

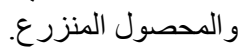

